\title{
IDENTIFYING THE PROMOTERS OF STUDENTS' SUSTAINABLE BEHAVIOUR: AN EMPIRICAL STUDY
}

\author{
Dan Dacian Cuzdriorean ${ }^{1 *}$, Szilveszter Fekete ${ }^{2}$ and Alina Beattrice Vladu ${ }^{3}$ \\ ${ }^{122) 33}$ Babeș-Bolyai University, Cluj-Napoca, Romania
}

\section{Please cite this article as:}

Cuzdriorean, D.D., Fekete, S. and Vladu, A.B., 2020.

Identifying the Promoters of Students' Sustainable

Behaviour: An Empirical Study. Amfiteatru Economic,

22(54), pp. 432-446.

DOI: $10.24818 / \mathrm{EA} / 2020 / 54 / 432$

\section{Article History}

Received: 30 December 2019

Revised: 25 January 2020

Accepted: 4 March 2020

\begin{abstract}
The present empirical study assessed factors as environment, education, social pressure and government actions from the perspective of promoters of sustainable behavior of students. In this regard a survey was conducted in one of the largest university in Romania. Our results documented as having a significant impact only factors as education and environment. Our study aims to provide a benchmark in measuring future efforts made by universities in their quest to become sustainable. By examining students' views on sustainable development, the present study covers a quasi-non-existent segment in the academic literature. The importance of our study is grounded mainly on the assumptions on the Theory of planned behavior (Ajzen, 1991), which links the individuals' attitudes with their behavior. Implications of our results are also discussed.
\end{abstract}

Keywords: Sustainable university, sustainable behavior, sustainable development, students, higher education, Romania.

JEL Classification: Q01, I20, M41.

\footnotetext{
* Corresponding author, Dan Dacian Cuzdriorean - dan.cuzdriorean@econ.ubbcluj.ro
} 


\section{Introduction}

The results documented by Elliott and Wright (2013) revealed that students' opinions on sustainable development are almost non-existent in the literature. The present study aimed to fill this gap and also to identify the key factors that can model their sustainable behavior. Knowing the fact that the university where the survey was conducted laid the foundation for the implementation of a development program (called UBB for Sustainable Development), adopted as part of their sustainability agenda, we were interested to examine whether the efforts made in this direction are known and appreciated by to students. Moreover, we were interested to examine if such efforts were able to shape the sustainable behavior of students.

Addressing the need to develop a program in the direction of sustainable development, the university approached issues such as the following: (i) the need for implementing green policies at institutional level in conformity with both national and international requirements in sustainable area; (ii) improving green metrics of the university; (iii) the desire to bring the university up to the next level, in order to become a world class university, international visible; (iv) reducing the ecological footprint of the university. Regarding the ecological footprint, the concept was introduced by the American researcher William Rees in 1992 and refers to a calculation formula by which the Earth is divided by its number of inhabitants, resulting in the area that a natural or legal person needs to provide the necessary resources and to fully biodegrade the waste generated throughout its existence.

The UBB Goes green program included several minimal measures related to some important aspects as following: education (improving the curriculum, workshops and students events, developing brochures regarding the UBB Goes Green program, etc.); research (developing a web page dedicated to UBB Goes Green program, insert a Green button in Management research application of the university to be used to select relevant research in sustainability domain, etc.); operations (reducing the ecological footprint, waste and pollution control, etc.); community (organizing activities of sanitizing of public spaces, developing partnerships with different organizations from environmental area, empowering students and staff to act sustainable, etc.); governance (taking concrete measures in order to make sustainability among priorities for the university).

Despite the constant efforts undertaken, important questions arise related to the sustainable behavior of students as the following: What do students know about what makes their university sustainable? Does the measures undertaken by the university via sustainability has the potential to shape their sustainable behavior? What are the key factors acting like promoters of sustainable behavior?

In order to address above questions we used a questionnaire comprising key factors found as being related to sustainability efforts and impacting such behavior, as: environmental influence, education, social pressure, governmental actions and socio-demographic variables. In this regard, a sample of 138 accounting students (from undergraduate level, accounting and information management specialization) were surveyed, documenting that only education and environmental influence can have an influence on modeling the sustainable behavior of students.

Section 1 comprises the review of the scientific literature, section 2 comprises our methodology and research hypotheses, section 3 the results and discussion, while the last section concludes, presents the limits of the research conducted and future research avenues. 


\section{Review of the scientific literature}

The importance of our study is grounded mainly on the assumptions on the Theory of planned behavior (Ajzen, 1991), the one that extends the Theory of Reasoned Action (Fishbein and Ajzen, 1975), which links the individuals' beliefs with their behavior. Summarizing the concepts comprised in this particular theory, intention toward behavior, subjective norms and perceived behavioral control, can shape the individuals' behavioral intentions and further their behaviors.

Summarizing the results revealed by this theory we reduce the field of knowledge to the fact that attitudes explain human actions, the real behavior being the rational result of a behavioral intention and the attitude-behavior relation is a multidimensional one. Moreover, the perceived behavioral control (concept underlying this theory) highlights that not all behaviors of individuals are under their direct control, instead of that, such behaviors rather vary on a scale from very well controlled to out of control (Ajzen, 1991). According to the theory of planned behavior the intention is the basis of its achievement, being in turn determined by three factors: the attitude regarding a certain behavior; subjective norm (social pressure from family or friends) and perceived behavioral control (Balog and Cristescu, 2009). As approached in Balog and Cristescu's (2009) study, perceived behavioral control refers to the perception of the ease or difficulty of performing a certain behavior, a perception that is based on both the individual's previous experiences and the ability to anticipate potential obstacles. Approaching the attitudes of individuals in relationship to certain steps taken in the environment in which they belong, attitudes can vary from positive to negative depending on their perception. The way in which individuals form their opinions and subsequently form their attitudes can be successfully shaped through education.

Stern (2000) asserted that our behaviors are having an unprecedented impact on our natural environment. Looking for long term solutions to limit such impact, universities were found as being in the position of taking greater responsibility in this regard. Working in a form of cross-border consortia, such organizations can form the foundation for creating awareness for an outstanding number of individuals, in terms of finding and promoting sustainable solutions. Being fully aware of their important role, universities all over the world, began the debate on the content of sustainability and to find ways to integrate it into their policies, organization and activities (Van Weenen, 2000). As a result, sustainability development became one of the biggest challenges of the twenty-first century (Van Weenen, 2000) both in academia and beyond (Pop et al., 2012). Scholars also supported the constant efforts undertaken by universities in order to actively promoting and advancing sustainability, by developing comprehensive managerial models for how a sustainable university should be (Velazquez et al., 2006) or by offering extensive reviews of the methods used to pursue the concept of sustainable university (Amaral et al., 2015). Others, like Elliott and Wright (2013), emphasized the fact that universities are well placed to educate and influence future leaders both on goals and importance of sustainability.

Nowadays, universities are the ones who grant the highest degrees of education and obviously the ones with the most important impact in shaping individuals` beliefs and impacting further their attitudes (Velasquez et al., 2006). Moreover, universities able to foster sustainability in education is empowering individuals to become global citizens fully aware of the problems around them, while their skills can impact significantly our environment in a positive way. 
As such, sustainability skills as: using our resources efficiently in order to limit the impact on the environment, capacity of long-term planning, understanding how human activity is affecting the environment and develop a solving problems capacity, etc. are important to be achieved by young people and not only. For this to happen, universities should take action and actively incorporate and promote sustainable development. In this case, universities are the ones that can lead by example. By developing a curriculum addressing topics from social and environmental perspective, can help individuals to act constantly on sustainability. One basic means of persuading individuals to engage in sustainable behaviors is to make available for the desired behaviors and actions and explain the consequences of each (as suggested by McKenzie-Mohr, 2000). As Gifford (2011) concluded people`s dearth of knowledge is due to the lack of exposure to information, and education can be a primary direction linked to greater responsiveness to engage in sustainability (Gifford and Nilsson, 2014).

Having as main objective the goal of educating individuals for the future, a sustainable university must favor a proactive attitude regarding the involvement of students in sustainability-related demarches and lastly, its agenda on sustainable development should be oriented mainly towards educating the young generation, as equal partners in the quest for success.

One the other hand, education can be completed by information. In this respect, Gifford and Nilsson (2014) asserted that is unlikely for an individual to engage deliberately in sustainable behavior change if one is not informed about the problem, potential consequences and proactive positive actions. As Delmas et al. (2013) and Osbaldiston and Schott (2012) concluded in their studies, information can play a role of paramount importance when shaping pro-environmental actions of individuals.

Earlier studies like those conducted by Grinstein and Nisan (2009) found that governmental pro-environmental actions are extremely useful for shaping sustainability on individuals' behavior. Previous studies as those conducted by Gonzales at el. (1988) and Burn and Oskamp (1986), documented that public commitments to engage in sustainable behavior (they were referring to consumers behavior) has the potential to increase such demarches. Realizing the importance of such demarches and their impact on society, regulators are engaging more actively in the cause of sustainable development. For instance, at European level, the European Council endorsed the 2030 Agenda, a political document to which the member states have committed themselves to act on a sustainable way, on three dimensions as following: economic, social and environmental (European Commission, 2019).

Recent studies, as those conducted by White et al. (2019) documented that social norms, social identities and social desirability have the potential to shift individuals to become more sustainable. Similarly, Peattie (2010) observed that what is socially accepted and approved in a given context has a powerful influence on sustainable behavior of individuals, particularly for individuals who wish to belong to a certain group of people (similar findings were documented by Gleim et al. (2013)).

Examining the impact of social norms on individuals, both studies conducted by White and Simpson (2013) or Dwyer et al. (2015) documented that such norms can predict behavior related to recycling or conserving energy. Referring to descriptive norms, Reno et al. (1993) concluded that those norms can be strong predictors of sustainable behaviors of consumers comparing to other factors. Other empirical findings documented that individuals are engaging much more in sustainable practices in cases of: individuals trying to make a positive 
impression on others (Green and Peloza, 2014); in-group members are doing the same (Han and Stoel, 2017) or there is an in-group attachment (Grinstein and Nisan, 2009).

Assessing the gender differences in terms of sustainable behavior, the empirical study conducted by Brough et al. (2016) documented that males avoid appearing eco-friendly, because this demarche is associated with the green-feminine stereotype. As such, for purposes of gender identity maintenance, males reject adopting green behavior, as stated above, regarded sometimes as green manipulation. Previous studies as those conducted by Eagly (2009) concluded that females exhibit more sustainable behaviors in relation with consumption.

Summarizing the above, various factors can impact the sustainable behavior of individuals. Despite its importance, the assessment of external factors determining and promoting the sustainable behavior of individuals and causal regarding sustainable behavior received little attention in the literature (Figueroa-Garcia et al., 2018). Moreover, as previous literature documented so far, understanding the causes and impacts of key factors, including their linkages (environmental, education, social, etc.) in building a sustainable behavior should be a focal areas in curricula of universities all round the world (Dabija et al., 2017).

\section{Methodology and research hypotheses}

This particular quantitative research measures the impact of some factors on students' sustainable behavior. For this purpose we collected data based on a questionnaire with closed questions on paper-pencil support, the answers being measured on the 5-step Likert scale (from "total disagreement" = 1 to "total agreement" $=5$ ). The structural equation modeling (SEM) hypotheses (presented below) were tested using the Partial least squares method (PLS). Data analysis was performed using SmartPLS statistical software, version 3.2.8. The sample consisted of students from the largest university in Romania. The sample volume was of 138 respondents. According to Barclay et al. (1995) the minimum sample size must be ten time the number of arrows pointing to a specific construct (number of causal relations defined in the structural model. In our case this is $10 \times 5=50$ observations, which is much less than our sample of 138 observations, which means that the minimum criterion is satisfied. The questionnaire applied was previously pre-tested to ensure that both language and the order of the questions are appropriate.

The purpose of this study was to examine the impact of factors as environment, education, social pressure and government actions from the perspective of promoters of sustainable behavior of students. The items (indicators) comprised in our model are detailed in table no. 1 below. Items were defined based on previous literature regarding sustainable behaviors among individuals, special attention being granted to the framework proposed by FigueroaGarcia et al. (2018). The items referring to UBB Goes Green program were developed based on the sustainability policy of the university were our study was conducted (UBB, 2016). 
Table no. 1: Indicators variables and explanations of the items comprised in our model

\begin{tabular}{|c|c|}
\hline $\begin{array}{l}\text { Indicator } \\
\text { variables }\end{array}$ & Explanations \\
\hline \multicolumn{2}{|r|}{ Demographic values (DMG) } \\
\hline DMG_1 & Age \\
\hline DMG_2 & Gender \\
\hline DMG_3 & Working experience \\
\hline \multicolumn{2}{|r|}{ Sustainable behavior of students (SCS) } \\
\hline SCS_1 & $\begin{array}{l}\text { My daily routine comprises concrete activities towards promoting safe } \\
\text { choices towards the environment (based on Figueroa-Garcia et al., 2018) }\end{array}$ \\
\hline SCS_2 & $\begin{array}{l}\text { I do not like to travel on long distances and consume local products in order } \\
\text { to protect the environment }\end{array}$ \\
\hline SCS_3 & $\begin{array}{l}\text { I am extremely motivated to make any changes necessary in order to protect } \\
\text { the environment, this meaning even to stop consuming or stop doing } \\
\text { activities that hurts our planet }\end{array}$ \\
\hline SCS_4 & $\begin{array}{l}\text { Please indicate the level of awareness of UBB Goes Green program } \\
\text { developed by your university }\end{array}$ \\
\hline SCS_5 & $\begin{array}{l}\text { I read everything related to sustainability actions undertaken by my } \\
\text { university and inform myself on the topic on regular basis }\end{array}$ \\
\hline SCS_6 & $\begin{array}{l}\text { I am willing to participate to sustainability surveys promoted by my } \\
\text { university and give my best to improve sustainability agenda of my } \\
\text { university }\end{array}$ \\
\hline SCS_7 & I am willing to collaborate/work on my campus sustainability projects \\
\hline \multicolumn{2}{|r|}{ Environmental influence (ENVIN) } \\
\hline ENVIN_1 & $\begin{array}{l}\text { Someone from my family / friends motivated me to act in a sustainable way } \\
\text { (based on Figueroa-Garcia et al., 2018) }\end{array}$ \\
\hline ENVIN_2 & $\begin{array}{l}\text { Until now, I participated at least once on voluntary works and projects } \\
\text { involving sustainability focus (based on Figueroa-Garcia et al., 2018) }\end{array}$ \\
\hline ENVIN_3 & $\begin{array}{l}\text { Someone from my university (administrative personnel, professors) } \\
\text { motivated me to act in a sustainable way }\end{array}$ \\
\hline ENVIN_4 & $\begin{array}{l}\text { I am aware of the existence of sustainability events promoted by the students } \\
\text { organization from my university since they motivated me in this direction }\end{array}$ \\
\hline \multicolumn{2}{|r|}{ Education and Information (ED) } \\
\hline ED_1 & $\begin{array}{l}\text { I participated at courses, workshops or conferences related to sustainability } \\
\text { topic in my university (based on Figueroa-Garcia et al., 2018) }\end{array}$ \\
\hline ED_2 & $\begin{array}{l}\text { Someone from my university taught me how to save: energy, water, } \\
\text { electricity, etc.) (based on Figueroa-Garcia et al. (2018) }\end{array}$ \\
\hline ED_3 & $\begin{array}{l}\text { I want to learn more about the UBB Goes Green program in my university, } \\
\text { its programs, and the related opportunities available for me }\end{array}$ \\
\hline ED_4 & I am aware of my campus sustainability projects \\
\hline ED_5 & $\begin{array}{l}\text { I receive on regular basis brochures /information from my university related } \\
\text { to its sustainability agenda }\end{array}$ \\
\hline ED_6 & $\begin{array}{l}\text { In the last years, my university increased the number of sustainability related } \\
\text { general education in the curriculum }\end{array}$ \\
\hline ED_7 & $\begin{array}{l}\text { Please rank the importance of sustainability topic in your education and } \\
\text { future development }\end{array}$ \\
\hline
\end{tabular}




\begin{tabular}{|c|c|}
\hline $\begin{array}{l}\text { Indicator } \\
\text { variables }\end{array}$ & Explanations \\
\hline ED_8 & $\begin{array}{l}\text { I consider that my university is making constant efforts to expand the } \\
\text { opportunities for sustainability (reducing greenhouse emissions, selective } \\
\text { waste, reducing energy, developing green roofs, etc.) }\end{array}$ \\
\hline ED_9 & $\begin{array}{l}\text { I am feeling an important part of the sustainability agenda of my university } \\
\text { being equally involved in its projects }\end{array}$ \\
\hline ED_10 & $\begin{array}{l}\text { I would like for my university to allocate funding for sustainability } \\
\text { development and research since I am passionate about this topic and I would } \\
\text { like to get involved }\end{array}$ \\
\hline ED_11 & $\begin{array}{l}\text { I saw concrete measures taken by my university towards implementing } \\
\text { activities comprised in their UBB Goes Green program and respect their } \\
\text { sustainability agenda }\end{array}$ \\
\hline \multicolumn{2}{|r|}{ Social pressure (SP) } \\
\hline SP_1 & $\begin{array}{l}\text { I felt pressure from my family and friends to engage in activities involving } \\
\text { the benefit of environment (based on Figueroa-Garcia et al., 2018) }\end{array}$ \\
\hline SP_2 & $\begin{array}{l}\text { I felt pressure from my university to engage in activities involving the benefit } \\
\text { of environment }\end{array}$ \\
\hline SP_3 & $\begin{array}{l}\text { I felt pressure from the students` organizations in my faculty to engage in the } \\
\text { pro-environmental projects developed }\end{array}$ \\
\hline \multicolumn{2}{|r|}{ Government actions (GA) } \\
\hline GA_1 & $\begin{array}{l}\text { The government is motivating the sustainable behavior in my country (based } \\
\text { on Figueroa-Garcia et al., 2018) }\end{array}$ \\
\hline GA_2 & $\begin{array}{l}\text { The government is very much involved in developing regulations in favor of } \\
\text { the environment (based on Figueroa-Garcia et al., 2018) }\end{array}$ \\
\hline GA_3 & $\begin{array}{l}\text { I feel motivated by the actions of the government to behave more sustainable } \\
\text { towards the environment }\end{array}$ \\
\hline GA_4 & $\begin{array}{l}\text { I am aware of the government programs in favor of the environment (e.g. } \\
\text { increasing renewable energy infrastructure, increasing selective waste, Rabla } \\
\text { program, etc.) }\end{array}$ \\
\hline
\end{tabular}

According to Figueroa-Garcia et al. (2018), the role of the state as a motivator or limiter of sustainable behavior is already acknowledge by the literature. Also, social pressure is approached by Figueroa-Garcia et al. (2018) and explained through norms constructed for community life, where individuals are willing to try to adhere to such norms in order to be part of a group. When it comes to social environmental influence, the authors asserted that such factor have a decisive influence in the development of sustainable behavior so as education. As such, all four factors impacting the sustainable behavior are highly approached in the literature and their influence and impact being empirically documented. As such, Figueroa-Garcia et al. (2018) conducted an empirical study examining social factors that determine sustainable consumption behavior in the community of Madrid, as: environment, education/information, social pressure, government actions, market conditions, demographic variables. The results of their empirical study documented that education and environment has the potential to impact the sustainable behavior of consumers.

In terms of demographic variables we selected age, gender and work experience considering that such variables can have an impact on the endogenous variable assessed. For instance, 
young people are known as embracing more the sustainability demarches (Dabija et al., 2017), while women are known as being more into sustainability activities (Brough et al., 2016). Contrary to Figueroa-Garcia et al. (2018) we did not select the level of education since our sample comprised only $3^{\text {rd }}$ year accounting students.

Since our paper investigates potential factors impacting students' sustainable behavior we developed the following research hypotheses to be tested, based on the model developed previously by Figueroa-Garcia et al. (2018):

- $\boldsymbol{H}_{1}$ : Government actions can shape the sustainable behavior of students.

- $\boldsymbol{H}_{2}$ : Social pressure have an important impact in shaping the sustainable behavior of students.

- $\boldsymbol{H}_{3}$ Environmental influence has a major impact on developing the sustainable behavior of students.

- $\boldsymbol{H}_{4}$ : Education / information is by far the most important factor in the development of sustainable behavior of students.

- $\boldsymbol{H}_{5}$ : Demographic variables as age, gender and working experience affect the sustainable behavior of students.

\section{Results and discussion}

Given the fact that the role of students in sustainability agenda of universities is extremely important, we assessed their sustainable behavior trying to identify the core factors impacting such behavior. All the factors assessed were external, in this regard is out of the scope of our study to focus on psychological and internal factors shaping this particular behavior. Similar to the study conducted by Figueroa-Garcia et al. (2018), we aimed to examine factors contributing to sustainable behavior by generating a model that is able to explain such behavior. As such, we partially selected from Figueroa-Garcia et al. (2018) and used the following variables as exogenous: environmental impact, education, social pressure, government actions and demographic, as tested the model using Partial Least Squares Structural Equation Modeling (PLS-SEM), and using SmartPLS version 3.2.8 statistical software.

A full breakdown of respondents' characteristics is found in table no. 2 .

Table no. 2: Sample description

\begin{tabular}{|l|c|}
\hline & Number of responses \\
\hline Questionnaire sent out & 186 \\
\hline Answers received (individual and group) & 155 \\
\hline Response rate (\%) & $83.33 \%$ \\
\hline Incomplete answers & 17 \\
\hline Valid (complete) answers & 138 \\
\hline Valid answers rate (\%) & $74.19 \%$ \\
\hline $\begin{array}{l}\text { of which } \\
\text { Women: }\end{array}$ & $117(85 \%)$ \\
\hline Men: & $21(15 \%)$ \\
\hline
\end{tabular}


As can be noticed in table no. 2, our sample consisted of 138 respondents, the distribution of the sample being: $85 \%$ women and $15 \%$ men, aged between $20-41$ years, with a mean of 21,15 years. All our respondents were undergraduates from the $3^{\text {rd }}$ year of study, accounting specialization, Romanian line of study.

Our data was collected via survey, using a questionnaire comprising 29 items assessed (amounting 4.495 data) based on a 5 point Likert scale. Our endogenous variable was the sustainable behavior of students, while the exogenous variables used were as stated above: environmental impact, education, social pressure, government actions and demographic. After debugging the database and eliminating the observations for missing data (incomplete answers), our sample finally included 138 observations with 29 indicators and 4.002 data, which was used for our initial model (the first theoretical path model). After refining our research and proposing a second, improved path model our sample included the same 138 observations, but with only 9 indicators, using a total of 1.242 data.

As the development of the initial theoretical path model is concerned, we considered the latent factors identified in previous literature as exogenous variables, i.e. demographic characteristics (DMG), environmental influences (ENVIN), education (ED), social pressure (SP) and government actions (GA), the latent endogenous variable being the sustainable behavior of students (SCS). All of these latent variables are operationalized in observable indicators as previously explained and graphically presented on figure no. 1; for the measurement model we use the reflective model.

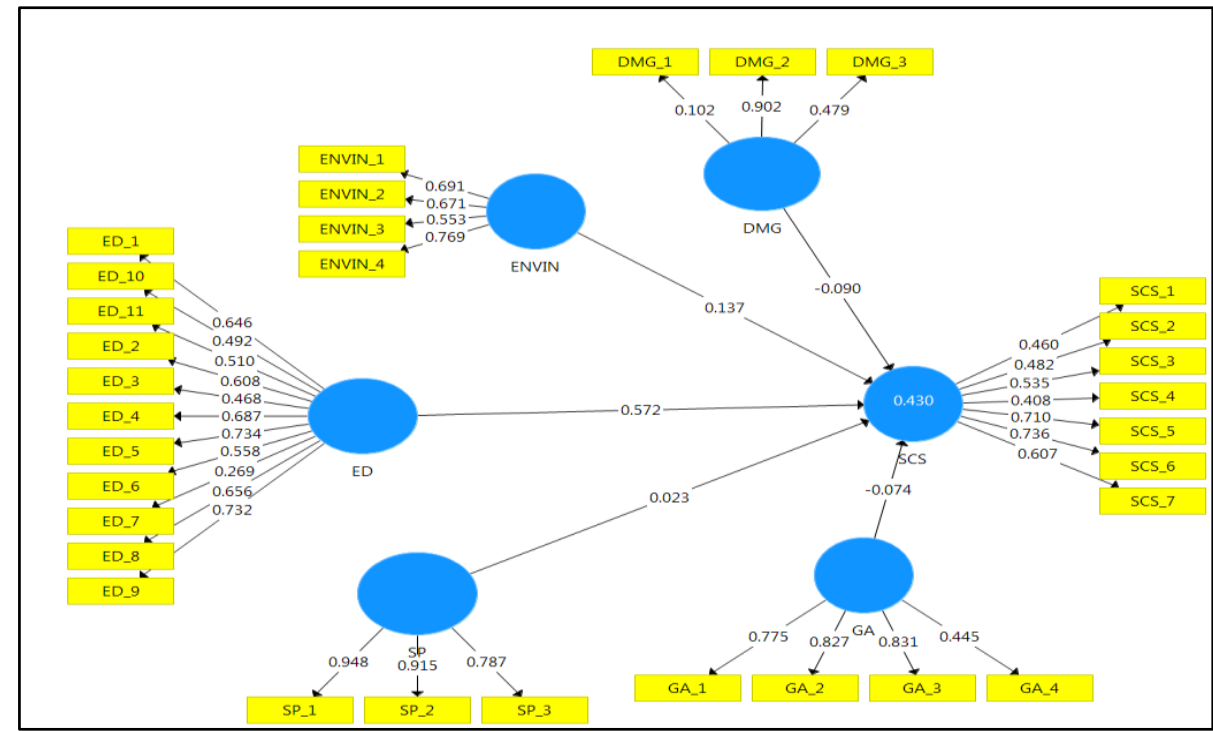

Figure no. 1: Initial theoretical path model and results of the PLS-SEM analysis Source: Authors 'projection

The initial results show: (a) the indicators' loadings from the measurement model (the outer model of the exogenous latent variables), (b) the path or regression coefficients for the structural model (the inner model) and (c) the $\mathrm{R}^{2}$ values for the latent endogenous variables. In this model we have only one endogenous variable that is the sustainable behavior of 
students (SCS), therefore the $\mathrm{R}^{2}$ value is 0.430 , meaning this model explains $43 \%$ of the variance of SCS.

As the path regressions are concerned, these indicate the expected statistical significance of relationship between the exogenous and endogenous latent variables: high/low coefficients indicate possible statistically significant/insignificant relationships, significance being further tested by bootstrapping method. In our construct only two latent variables seem to have significant impact on SCS: education (0.572) and environmental influence (0.137). Thus, we retain only these variables when formulating the second, improved model.

The indicator loadings indicate the correlation between the observable indicator variables and the unobservable latent variables. According to Hair et al. (2014), in order to evaluate reflective measurement models, the value of indicator loadings should exceed an empirical threshold of 0.708 , since maintaining such indicators in the model leads to decrease in the composite reliability and convergent validity (AVE) of the model. This is true for both endogenous and exogenous variables. For example, for the latent variable "Education" we maintain only 2 indicators out of 11, since only these have loadings > 0.708: ED_5 (0.734) and ED_9 (0.732); we also eliminate 5 out of 7 indicators from SCS.

We proceed to formulate a new construct for the improved model taking in consideration path regressions and indicator loadings. Furthermore, we added a new causal relation in the structural model: ENVIN $\rightarrow$ ED. The results are presented in figure no. 2 below.

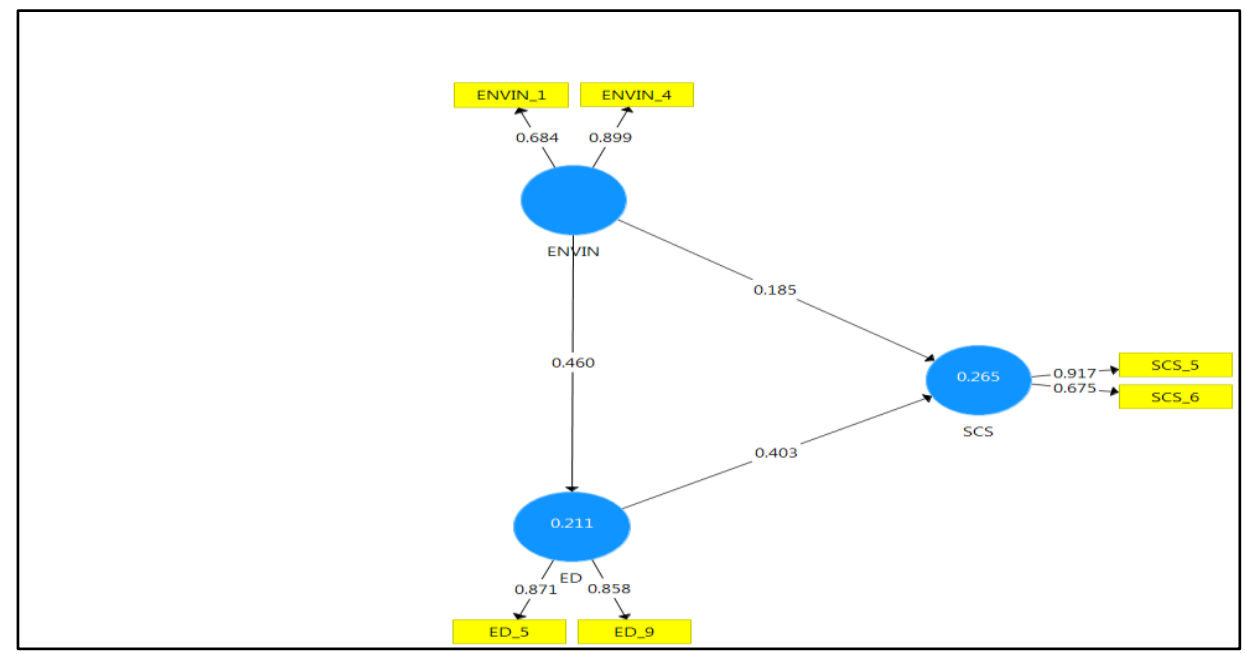

Figure no. 2: Improved theoretical path model and results of the PLS-SEM analysis Source: Authors`projection

We can immediately observe a sharp decrease in the explanatory power of the improved model compared to the initial one $\left(\mathrm{R}^{2}=0.265<0.430\right)$. In order to evaluate the reliability and validity of the model, we calculate indicator reliability, composite reliability, convergent validity (AVE, Average Variance Extracted), and the Discriminant Validity of the improved model. Results are summarized in table no. 3 . 
Table no. 3: Reliability and validity of the reflective measurement models

\begin{tabular}{|c|c|c|c|c|c|}
\hline $\begin{array}{c}\text { Latent } \\
\text { Variable }\end{array}$ & Indicators & $\begin{array}{c}\text { Indicator } \\
\text { Reliability }\end{array}$ & $\begin{array}{c}\text { Composite } \\
\text { Reliability }\end{array}$ & AVE & $\mathbf{R}^{\mathbf{2}}$ \\
\hline ED & ED_5 & 0.871 & 0.855 & 0.747 & 0.211 \\
\hline & ED_9 & 0.858 & & & \\
\hline ENVIN & ENVIN_1 & 0.684 & 0.775 & 0.638 & - \\
\hline & ENVIN_4 & 0.899 & & & \\
\hline SCS & SCS_5 & 0.917 & 0.783 & 0.649 & 0.265 \\
\hline & SCS_6 & 0.675 & & & \\
\hline
\end{tabular}

Note: Education (ED), environmental influence (ENVIN), sustainable behavior of students (SCS).

As we can see, all outer loadings of indicators (Indicator reliability) are higher than the 0.708 threshold, except for ENVIN_1 and SCS_6. Indicator with the greatest external loading is SCS_5 (0.917) and the smallest is SCS_6 (0.675). We accept this compromise, since the value of Composite Reliability is higher than 0.70 considered by Faul et al. (2009) as satisfactory.

According to Duarte and Raposo (2010, p.463) discriminant validity indicates the extent to which a given construct is different from other latent constructs. For adequate discriminant validity, this measure should be greater than the variance shared between the construct and other constructs in the model. Since all values are below 0.85 , we may consider the model satisfies this "adequate" discriminant validity condition, as presented in table no. 4.

Analysis of collinearity problems is performed by the Variance Inflation Factor (VIF) as proposed by Chin (1998); the author considers that collinearity is not problematic if VIF values are below the threshold of 5. In this model VIF values are less than 1, 3 therefore we may conclude there are no collinearity issues in the construct.

Table no. 4: Discriminant Validity and Collinearity Statistics

\begin{tabular}{|c|c|c|c|c|c|c|}
\hline & \multicolumn{3}{|c|}{$\begin{array}{c}\text { Discriminant Validity } \\
\text { (based on HTMT Criterion) }\end{array}$} & \multicolumn{2}{c|}{$\begin{array}{c}\text { Collinearity } \\
\text { Statistics (VIF) }\end{array}$} \\
\hline & ED & ENVIN & SCS & Decision & ED & SCS \\
\hline ED & - & - & - & Yes & - & 1.268 \\
\hline ENVIN & 0.807 & - & - & Yes & 1.000 & 1.268 \\
\hline SCS & 0.805 & 0.694 & - & Yes & - & - \\
\hline
\end{tabular}

Note: Education (ED), environmental influence (ENVIN), sustainable behavior of students (SCS).

Having all this information, we may further test the hypotheses issued in the research question section of the paper. For this purpose, we collect path coefficient to measure the sign and strength of relationship between latent variables, and for significance testing we use $\mathrm{t}$-value obtained by Bootstrapping method and the $\mathrm{p}$-value. The result of hypotheses testing is also disclosed in the last column of table no. 5 . 
Table no. 5: Hypothesis testing based on initial model

\begin{tabular}{|c|c|c|c|}
\hline Hypotheses & $\begin{array}{c}\text { Path } \\
\text { Coefficient }\end{array}$ & $\begin{array}{c}\text { t-value (Bootstrap) } \\
\text { p-value }\end{array}$ & $\begin{array}{c}\text { Result } \\
\text { of Hyp testing }\end{array}$ \\
\hline H1: GA $\rightarrow$ SCS & -0.074 & 0.835 & Rejected \\
\hline & & 0.404 & \\
\hline H2: SP $\rightarrow$ SCS & 0.023 & 0.266 & Rejected \\
\hline & & 0.790 & \\
\hline H3: ENVIN $\rightarrow$ SCS & 0.137 & 1,255 & Rejected \\
\hline H4: ED $\rightarrow$ SCS & & 0.210 & \\
\hline & $\mathbf{0 . 5 7 2}$ & $\mathbf{6 . 5 4 5}$ & Accepted $^{* * *}$ \\
\hline H5: DMG $\rightarrow$ SCS & -0.090 & $\mathbf{0 . 0 0 0}$ & \\
\hline & & 0.934 & Rejected $^{-}$ \\
\hline
\end{tabular}

Note: Government actions (GA), sustainable behavior of students (SCS), social pressure (SP), environmental influence (ENVIN), education (ED).

We can see, that on the basis of the initial theoretical path model only the Education (ED) variable seems to have a positive and statistically significant impact on the sustainable behavior of students (SCS), therefore we accept only $\mathrm{H} 4$, the rest of hypotheses being rejected accordingly.

On the other hand, we constructed an improved model by eliminating the shortcomings of the first model. This new construct comprises only two latent variables (ENVIN and ED), the relationship between variables being more thoroughly explored by defining both Education (ED) and sustainable behavior of students (SCS) endogenic variable (table no. 6).

Table no. 6: Hypothesis testing based on improved model

\begin{tabular}{|c|c|c|c|}
\hline Hypotheses & $\begin{array}{c}\text { Path } \\
\text { Coefficient }\end{array}$ & $\begin{array}{c}\text { t-value (Bootstrap) } \\
\text { p-value }\end{array}$ & $\begin{array}{c}\text { Result } \\
\text { of Hyp testing }^{\text {Holn }}\end{array}$ \\
\hline H3: ENVIN $\rightarrow$ SCS & $\mathbf{0 . 1 8 5}$ & $\mathbf{2 . 0 2 6}$ & Accepted $^{* *}$ \\
\hline & & 0.043 & \\
\hline H4: ED $\rightarrow$ SCS & $\mathbf{0 . 4 0 3}$ & $\mathbf{4 . 8 5 0}$ & Accepted $^{* * *}$ \\
\hline & & 0.000 & \\
\hline
\end{tabular}

As we can conclude from table no. 6, both latent variables have significant impact on SCS (ENVIN is significant on 0.05 level, while and ED is significant on 0.01 level), therefore we may accept both $\mathrm{H} 3$ and $\mathrm{H} 4$ hypotheses. Thus, in addition to the accepted education variable in the initial model tested also the variable environment seems to have an impact on the analyzed behavior. In conclusion, our results document the fact that two of the factors tested (education and environment) have a significant impact on the sustainable behavior of students as opposed to the other factors analyzed such as: government actions, social pressure, age, gender, and level of experience. Similar results were obtained by Figueroa-Garcia et al. (2018) when they tested the impact of several social factors on the sustainable behavior of consumers in the community of Madrid.

\section{Conclusions}

The present study identifies and analyzes the decisive factors in modeling the sustainable behavior of the students, placing at the base of its formation only the education and the 
influence of the environment. Our results are useful for both practitioners and researchers examining the sustainable behavior of individuals in various contexts, the way such behavior can be modeled, and which are the factors underlying its formation.

Given the results obtained, universities should emphasize the importance of developing sustainable development programs and follow proactive demarches towards identifying and analyzing the factors that impede their implementation. Also, given their training role, higher education institutions must place their concerns on educating young people in a culture of "sustainability". Moreover, since the impact of the academic environment on social trends is well known, when such knowledge institutions become aware of the importance of sustainable development, the concept receives increased attention at the societal level. Finally, in order to ensure that green policies achieve the expected effects, it is desirable that government institutions empowered to develop and implement them should focus on the power of collective action and form partnerships with both educational institutions and business environment. Together they can take all the necessary measures to develop effective channels of communication of these policies and raise awareness of the importance of ecological education. The ultimate goal of our research is to support the importance of citizen-centered educational approaches of the future, the formation of adults with a high degree of awareness of ecological aspects.

Given the small number of respondents, a limitation of our study refers to the volume of our sample. Another important limitation concerns the subjectivity of the answers offered by our respondents. Future research could evaluate the progress made by universities in their quest to become sustainable and how they involve their students in this endeavor. Also, future studies could focus on identifying the factors that prevent universities and students from collaborating on all aspects of the sustainability agenda.

\section{References}

Ajzen, I., 1991. The theory of planned behavior. Organizational Behavior and Human Decision Processes, 50(2), pp.179-211.

Amaral, L., Martins, N. and Gouveia, J., 2015. Quest for a sustainable university: a review. International Journal of Sustainability in Higher Education, 16(2), pp.155-172.

Balog, A., and Cristescu, I., 2009. Teorii şi modele ale acceptării noilor tehnologii. Revista Română de Interacţiune Om-Calculator, 2(2), pp.147-160.

Barclay, D., Thompson, R., and Higgings, C., 1995. The Partial Least Square (PLS) Approach to Causal Modelling: Personal computer adoption and use as an illustration. Technology Studies, 2(2), pp.285-309.

Brough, A.R., Wilkie, J.E., Ma, J., Isaac, M.S. and Gal, D., 2016. Is Eco-Friendly Unmanly? The Green-Feminine Stereotype and Its Effect on Sustainable Consumption. Journal of Consumer Research, 43(4), pp.567-582.

Burn, S.M. and Oskamp, S., 1986. Increasing Community Recycling with Persuasive Communication and Public Commitment. Journal of Applied Social Psychology, 16(1), pp.29-41.

Chin, W., 1998. The Partial Least Approach to Structural Equation Modelling. In: A. Marcoulides (ed). Modern Methods for Business Research. 1st ed. New Jersey: Lawrence Erlbaum Associates. pp. 295-336. 
Dabija, D., Postelnicu, C., Dinu, V. and Mihăilă, A., 2017. Stakeholders' perception of sustainability orientation within a major Romanian University. International Journal of Sustainability in Higher Education, 18(4), pp.533-553.

Delmas, M.A., Fischlein, M. and Omar I.A., 2013. Information Strategies and Energy Conservation Behavior: A Meta-Analysis of Experimental Studies from 1975 to 2012. Energy Policy, 61(C), pp.729-739.

Duarte, P. and Raposo, M., 2010. A PLS Model to Study Brand Preference: An Application to the Mobile Phone Market. In: V. Esposito Vinzi, W. Chin, J. Henseler and H. Wang (eds.). Handbook of Partial Least Squares. Berlin: Springer. pp.449-477.

Dwyer, P.C., Maki, A. and Rothman, A.J., 2015. Promoting Energy Conservation Behavior in Public Settings: The Influence of Social Norms and Personal Responsibility. Journal of Environmental Psychology, 41, pp.30-34.

Eagly, A.H., 2009. The His and Hers of Prosocial Behavior: An Examination of the Social Psychology of Gender. American Psychologist, 64(8), pp.644-658.

Elliott, H. and Wright, T., 2013. Barriers to sustainable universities and ways forward: a canadian students' perspective. The 3rd World Sustainability Forum. [pdf]. Available at: <http://sciforum.net/conference/wsf3/paper/2304/download/manuscript.pdf?〉> [Accessed 03 December 2019].

European Commission, 2019. Reflection Paper "Towards a Sustainable Europe By 2030". [pdf]. Available at: <https://ec.europa.eu/commission/sites/beta-political/files/ rp_sustainable_europe_30-01_en_web.pdf> [Accessed 03 December 2019].

Faul, F., Erdfelder, E., Buchner, A., and Lang, A.-G., 2009. Statistical power analyses using $\mathrm{g}$ *power 3.1: Tests for correlation and regression analyses. Behavioral Research Methods, 41(4), pp.1149-1160.

Figueroa-García, E.C., García-Machado, J.J. and Pérez-Bustamante Yábar, D.C., 2018. Modeling the Social Factors that Determine Sustainable Consumption Behavior in the Community of Madrid. Sustainability 10(8), pp.1-16.

Fishbein, M. and Ajzen, I., 1975. Belief, Attitude, Intention, and Behavior: An Introduction to Theory and Research. Reading: Addison-Wesley.

Gifford, R., 2011. The Dragons of Inaction: Psychological Barriers That Limit Climate Change Mitigation and Adaptation. American Psychologist, 66(4), pp.290-302.

Gifford, R., 2014. Environmental Psychology Matters. Annual Review of Psychology, 65(1), pp.541-579.

Gifford, R. and Nilsson, A., 2014. Personal and Social Factors that Influence ProEnvironmental Concern and Behaviour: A Review. International Journal of Psychology, 49(3), pp.141-157.

Gleim, M.R., Smith, J.S., Andrews, D. and Cronin Jr, J.J., 2013. Against the green: A multimethod examination of the barriers to green consumption. Journal of Retailing, 89(1), pp.44-61.

Gonzales, M.H., Aronson, E. and Costanzo, A., 1988. Using Social Cognition and Persuasion to Promote Energy Conservation: A Quasi- Experiment. Journal of Applied Social Psychology, 18(12), pp.1049-1066. 
Green, T. and Peloza, J., 2014. Finding the Right Shade of Green: The Effect of Advertising Appeal Type on Environmentally Friendly Consumption. Journal of Advertising, 43(2), pp.128-141.

Grinstein, A. and Nisan, U., 2009. Demarketing, Minorities, and National Attachment. Journal of Marketing, 73(2), pp.105-122.

Hair Jr., F.J., Sarstedt, M., Hopkins, L., and Kuppelwieser, V.G., 2014. Partial least squares structural equation modeling (PLS-SEM). European Business Review, 26(2), pp.106-121.

Han, T.I. and Stoel, L. 2017. Explaining Socially Responsible Consumer Behavior: A MetaAnalytic Review of Theory of Planned Behavior. Journal of International Consumer Marketing, 29(2), pp.91-103.

McKenzie-Mohr, D., 2000. New Ways to Promote Proenvironmental Behavior: Promoting Sustainable Behavior: An Introduction to Community-Based Social Marketing. Journal of Social Issues, 56(3), pp.543-554.

Osbaldiston, R. and Schott, J.P., 2012. Environmental Sustainability and Behavioral Science: Meta-Analysis of Proenvironmental Behavior Experiments. Environment and Behavior, 44(2), pp.257-299.

Peattie, K., 2010. Green Consumption: Behavior and Norms. Annual Review of Environment and Resources, 35(1), pp.195-228.

Pop, N.A., Roman, M., Săniuță, A., and Petrișoaia, C., 2012. Relationship Marketing, Engine of Sustainable Development and Organisational Change in the Romanian Business Environment. Amfiteatru Economic, 14(32), pp.349-364.

Rees, W.E., 1992. Ecological Footprints and appropriated carrying capacity: what urban economics leaves out. Environment and Urbanization, 4(2), pp.121-130.

Reno, R.R., Cialdini, R.B. and Kallgren, C.A., 1993. The Transsituational Influence of Social Norms. Journal of Personality and Social Psychology, 64(1), pp.104-112.

Stern, P.C., 2000. New Environmental Theories: Toward a Coherent Theory of Environmentally Significant Behavior. Journal of Social Issues, 56(3), pp.407-424.

$\mathrm{UBB}, 2016$. Decision regarding the implementation of the UBB for Sustainable development Program (UBB Goes Green) no. 21036/31.10.2016. [pdf] Available at: <https://www.ubbcluj.ro/ro/infoubb/files/InfoUBB_2016_10/Hotarare\%20privind\%20 Programul\%20,UBB\%20pentru\%20Dezvoltarea\%20Sustenabila"\%20(UBB\%20Goes \%20Green)\%20CA\%2031.10.2016.pdf> [Accessed 03 Septembrie 2019].

Van Weenen, H., 2000. Towards a vision of a sustainable university. International Journal of Sustainability in Higher Education, 1(1), pp.20-34.

Velazquez, L., Munguia, N., Platt, A. and Taddei, J., 2006. Sustainable university: what can be the matter? Journal of Cleaner Production, 14(9-11), pp.810-819.

White, K., Habib, R. and Hardisty, D.J., 2019. How to SHIFT Consumer Behaviors to be More Sustainable: A Literature Review and Guiding Framework. Journal of Marketing: A Quarterly Publication of the American Marketing Association, 83(3), pp.22-49.

White, K. and Simpson, B., 2013. When Do (and Don't) Normative Appeals Influence Sustainable Consumer Behaviors? Journal of Marketing, 77(2), pp.78-95. 